\title{
Spreading the Word: The Microfoundations of Institutional Persuasion and Conversion
}

\author{
Paul Tracey \\ Cambridge Judge Business School \\ University of Cambridge \\ Trumpington St \\ Cambridge, UK \\ CB2 $1 \mathrm{AG}$ \\ Tel: +44 1223760471 \\ E-mail: p.tracey@jbs.cam.ac.uk
}

\begin{abstract}
I examine the micro-level processes involved when members of an organization seek to persuade others to internalize a new institutional logic. To do so I conduct a qualitative study of the Alpha course, an evangelizing movement designed to convert agnostics to a particular - and contested interpretation of Christianity. My analysis suggests that the process of persuading actors to adopt a new logic entails four distinct kinds of micro-institutional work and illustrates the dynamics underpinning each of them. It also delineates three discrete paths that targeted actors may follow in response to persuasive attempts. I contribute to organization theory by building a framework that conceptualizes the microfoundations of institutional persuasion and conversion. The framework illustrates the two-way nature of institutional communication and highlights the potential of emotion and ritual performance to connect actors with - and alienate actors from - institutional logics.
\end{abstract}

Key words: Institutional logics, persuasion, conversion, emotion, ritual performance

Acknowledgements: I am extremely grateful to Sarah Kaplan and three anonymous reviewers for giving me such constructive and detailed feedback on earlier drafts. I also thank Martin Kilduff, my former head of group at Cambridge, without whose encouragement I would not have embarked upon this research project. In addition, the paper benefitted greatly from the comments of Royston Greenwood, Nelson Phillips, Tina Dacin, Charles Galunic, Christian Hampel, Henri Schildt, Raina Brands, Ben Hardy, Kent Miller, Neil Stott, the OB reading group at CJBS, and the Organization Theory Research Group (OTREG). 
Institutional logics are sets of "material practices and symbolic constructions" that individuals and organizations draw upon and elaborate in different societal spheres (Friedland and Alford 1991, p. 248; Thornton et al. 2012). They represent discrete belief systems, each organized around a particular "substance" - a system of values that adherents seek to embody and reproduce. Logics cannot be directly observed, but become visible through "regimes of practice" constituted by distinct rules, roles and categories (Friedland 2013, 2014). Actors use logics to interpret and make sense of the world, but at the same time logics provide resources for relationship building, identity construction, and decision-making. Institutional settings are typically characterized by multiple institutional logics, which provide actors with inconsistent expectations about how to behave (Greenwood et al. 2011). From this perspective, actors inhabit systems of institutions in which different forms of value rationality compete for dominance.

The institutional logics that individual actors hold are not set in stone and may change over time (Rao et al. 2003). But why do actors come to adopt a new logic? One explanation is that those with vested interests in a given logic devote their energies to persuading others to convert to it - to accept its system of beliefs. Persuasion is fundamental to social behavior (Cialdini 2001), and while institutional researchers were initially slow to pay attention to the concept, a concern with the strategic use of influence is increasingly evident in the institutional literature. However, much institutional research on influence is focused at the field level and has been criticized for neglecting the possibility that micro-level pressures can at times be more important than macro-level pressures with respect to logic adoption (Smets et al. 2012). Moreover, it has largely ignored the nature of the micro-level communication that takes place when actors seek to promote a particular set of institutional beliefs to others (Kellogg 2011). In particular, there is little work that explores the role of emotion in this process (Voronov and Vince 2012) - yet emotion is known to play a key role in effective communication (Cornelissen 2011).

I respond to these criticisms by examining the microprocesses involved when members of an organization attempt to persuade other actors to convert to a different belief system. To do so I draw upon the notion of institutional work: "the purposive action of individuals and organizations aimed at creating, maintaining and disrupting institutions" (Lawrence and Suddaby 2006, p. 215). Specifically, I address the 
following questions: What kinds of micro-level institutional work are required to persuade actors to internalize an institutional logic? How do targets respond to these persuasive efforts? In answering these questions I study the Alpha course, a movement designed to convert agnostics to an evangelical Christian institutional logic. It is important to emphasize that many Christians do not accept this logic - there are profound differences between it and what many believe to be the core of Christianity.

The first Alpha course was established in a church in central London, the Holy Trinity Brompton, in the late 1970s. In 1990 the Reverend Nicky Gumbel was placed in charge of the course. He was concerned about falling church attendances and the apparent decline of Christianity in the UK. In response he embarked upon a radical strategy to expand Alpha throughout Britain and subsequently across the world. At the time of writing there are courses running in 169 countries and 112 languages over 27 million people have attended Alpha worldwide. The remarkable scale of the Alpha initiative and the success that it claims to have had in persuading non-churchgoers to become active Christians suggest that Alpha offers an intriguing opportunity to explore the dynamics of persuasion and conversion in institutional theory.

My findings indicate that the process of persuading actors - or "targets" (Dillard and Pfau 2002) - to internalize an institutional logic entails four distinct types of micro-institutional work: framing work, identity work, affective work, and performative work. However, enacting effectively these forms of work is challenging and requires high levels of skill. Moreover, targets do not respond uniformly to persuasive messages and may infer meaning that is very different from the intended meaning, which renders the outcomes of the persuasive process uncertain - conversion is by no means guaranteed.

In developing my arguments, I make two key contributions. First, I shed light on the role of emotion and performance in institutional dynamics. Specifically I show that, when used strategically in communication, emotion and performance have the potential to connect actors to institutional logics by intensifying the potency of messages and situating these messages in the context of a wider system of interpretation. I also highlight their volatile and unpredictable character, which can lead targets to become alienated from the logic being promoted. Second, I show the two-way nature of institutional 
communication. In particular, by highlighting the varied responses of targets in the context of successful and unsuccessful persuasion attempts, I build a richer understanding of how actors experience logics and construct meaning systems, one that takes seriously the agency of both targets and persuaders.

\section{Theoretical Context: Persuasion, Conversion and Emotion}

While institutional theorists seldom use the term persuasion, there is an institutional literature that considers how actors seek to influence others with respect to logic adoption. The dominant approach focuses on language (Lammers 2011) and often draws on the concept of framing - discursive work designed to construct meaning for others and mobilize collective action (Benford 1997) - from social movement theory. Some scholars have used the idea of injustice frames that provide opportunities for less powerful organizational members to mobilize action (Kellogg 2011; Scully and Creed 2005), others have focused on the struggle for meaning around the framing of particular ideas or events (Creed et al. 2002; Kaplan 2008). Regardless of how they use the concept, institutional theorists emphasize that framing facilitates logic adoption when frames tap into targets' interests, values and beliefs.

More recently, institutional research has also examined collective identity as a means of influencing logic adoption, emphasizing that shared identity is a key mechanism through which logics are linked to action (Meyer and Hammerschmid 2006; Mohr and Guerra-Pearson 2010; Thornton et al. 2012). In exploring this link, institutional theorists have again looked to social movement theory, arguing, for example, that collective identity allows potential reformers to build solidarity against adversaries (Kellogg 2009), and that it can be used strategically to convince movement participants to reject one logic in favor of another (Rao et al. 2003). The central idea is that persuading actors to internalize a logic involves building a shared definition of group membership, one that is rooted in common experiences.

Thus institutional theorists have developed a number of key insights into how actors can persuade others to accept a new logic. However, they have focused on a narrow range of influence strategies and largely ignore the significant body of work on strategic communication. I therefore turn to the psychological literature on persuasion in order to identify additional forms of influence that may be relevant in the context of logic adoption. 
While an agreed upon definition remains elusive, at the core of the persuasion literature is the idea that effective persuasion involves a measureable change in the attitudes of targets (Cialdini 2001; Dillard and Pfau 2002; Wood 2000). Kelman (1958) distinguished between 3 types of attitude change. The most superficial form is compliance, which occurs when a person accepts influence because s/he anticipates reward or approval. The second form is identification, which happens when a person accepts influence because s/he seeks acceptance by an individual or group. The most deep-rooted form - and the focus of this study - is internalization, which happens when an individual accepts influence because it is "intrinsically rewarding". In other words, it both informs and reflects her or his worldview and value system. This form of attitude change requires that communication resonates: for messages to persuade in this way targets need to "perceive the anchors on which the message is based as coming from within themselves" rather than being imposed on them by the communicator (Jowett and O'Donnell 2012, p. 38).

Arguably the most influential model of the persuasion process is the elaboration likelihood model, which builds on dual processing theory to posit 2 routes to persuasion - a peripheral and a central route (Bator and Cialdini 2000; Petty and Cacioppo 1986; Wood 2000). The peripheral route assumes that attitude change may be an intuitive and emotional process that relies on "cues" from the communicator and the context in which the communication takes place. Non-verbal dimensions of persuasion such as physical space, touch, and body language may be particularly important (Burgoon et al. 2002). By contrast, the central route assumes that attitude change depends on "a thoughtful consideration of the object or issue at hand" (Petty and Cacioppo 1986, p. 256). From this perspective, effective persuasion relies on the cognitive processing of information by targets - the content of messages is more important than the mode of delivery, the "attractiveness" of the communicator, or the setting in which messages are conveyed. In practice, the distinction between the peripheral and central routes to persuasion is not clearcut; sophisticated persuasive endeavors rely upon a combination of them (Bator and Cialdini 2000).

The persuasion literature offers a number of important ideas with the potential to shed light on the process of logic adoption. In particular, while, like the logics literature, it emphasizes language and cognition, persuasion research also points to the vital role of non-verbal aspects of communication: space, 
touch and body language, as well as the emotional dimension of persuasion, have been extensively examined. However, one of the weaknesses of the literature on persuasion - which is also a shortcoming of institutional theory - is that it focuses overwhelmingly on the role of the communicator; the targets of persuasive communication occupy a marginal role (Cornelissen 2011). Because in this study I am concerned with the targets as well as the senders of persuasive messages, I draw on the literature on conversion to help theorize logic adoption from multiple viewpoints.

While there are many definitions, there is relative agreement conversion involves a change in a person's sense of self and beliefs about the world: "To say that a man [sic] is 'converted' means...that religious ideas, previously peripheral in his consciousness, now take a central place, and that religious aims form the habitual centre of his energy" (James 1961/1902, p. 165). Much early work on conversion has been characterized as "passive", with the convert "driven into the arms of the group that manipulates him or her so as to exact... commitment to its belief system and institutional structure" (Straus 1979, p. 161). This suggests that converts are essentially brainwashed and their emotions manipulated through “overstimulation of the nervous system" (Snow and Machalek 1984, p. 179). In other words, conversion is portrayed as neither rational nor purposive. Rather, actors get caught up in a wave of ritualized emotion that is "not under the convert's control" (Richardson 1985, p. 165), or "drift" into conversion because of personal problems or social isolation without making a specific choice (Long and Hadden 1983).

A growing number of researchers has challenged the idea of the passive convert, emphasizing the role of active and volitional subjects who make a choice to convert (Robbins 1988). For example, Lofland and Stark (1965) propose that actors may facilitate their conversion by purposefully constructing social networks and affective ties with members of a particular religion. Other scholars have conceptualized prospective converts as "religious seekers" who desire personal transformation or emotional stimulation (Richardson 1985). Indeed, research has shown that even in apparently 'extreme' religious cults, converts are not necessarily subject to systematic manipulation and may attach their own meanings to rituals and other religious practices in an effort to achieve personal goals and reconstruct their identities (Snow and Machalek 1984). In other words, they may have a range of motivations to convert that exist independently 
of any social and emotional pressures to which they are subject (Balch and Taylor 1977).

Thus research on religious conversion has increasingly recognized that experiences of conversion are not homogenous. Crucially, this work has shown that conversion may comprise both active and passive elements and that personal transformation can be rooted in social relationships and/or the desire for a new identity and way of life (Bromley 2011). It also highlights the role of ritual in channeling and synthesizing systems of meaning and creating connections among participants (Goodman 2008;

Kilbourne and Richardson 1989; Snow and Machalek 1984).

More broadly, in examining both the persuasion and conversion literatures, what comes through especially strongly is the central role of emotion - a process in which "affective experiences... unfold over short periods of time" (Coté 2005, p. 510), often generated through ritual or ritualized practices. While seldom explicitly theorized in institutional research (but see Creed et al. 2010; DeJordy and Barrett 2014; Voronov and Vince 2012), emotions have been the focus of much attention elsewhere in management and its cognate disciplines (Stets and Turner 2014). Crucially, emotions "are meant to move us" (Elfenbein 2007, p. 346) and can have powerful effects on attitudes and beliefs.

Emotions are intimately connected to the human body and have a physiological component (Wentworth and Yardley 1994). However, the activation and expression of emotions are also socially constructed - normative expectations influence the emotions that people are 'supposed' to feel and display in particular situations (Turner 2007). In other words, it is through social relationships that emotions come to have meaning for those who experience them (Stets and Trettevik 2014). In the context of my study, insights into the way that emotions emerge through social interaction and influence behavior are most apparent in the sociological literature on ritual performance.

Rituals are "collectively produced, structured, and dramatic occasions that create a....shared definition of the situation within which participants are expected to express and confirm sanctioned ways of experiencing social reality" (Kunda 2006, p. 93). At their core, they are built on shared attention and emotion with the potential to create "collective effervescence" (Durkheim 1912). In other words, people are "doing things" with one another and they are "feeling things" with one another - "sharing the 
electricity or buzz generated by the event” (Rossner and Meher 2014, p. 202). When enacted successfully, rituals generate a sense of solidarity among participants as well as a common set of rules about what constitutes appropriate behavior; i.e., a shared symbolic order (Alexander 2004).

Drawing together the key ideas from my literature analysis, it is apparent that institutional theory is increasingly concerned with how organizations influence other actors to adopt new institutional logics this is how institutions recruit adherents to support them. However, consideration of the persuasion and conversion literatures suggests that it offers only a partial account. First, institutional research has focused mainly on language and identity. We know very little about the role of emotion, yet this has been shown to a play key role in persuasion and conversion. Second, much institutional research focuses only the actors seeking to persuade and seldom incorporates the perspective of potential converts. But targets do not respond uniformly to persuasive communication and may play active roles in their own conversion. Indeed, understanding the dynamics of persuasion and conversion requires analysis of both "successful" and "failed" cases (Tormala and Petty 2004). In order to address these shortcomings and to deepen our understanding of logic adoption at the micro-level, I study a religious movement designed to persuade others to internalize a new institutional logic. This represents an extreme case, one that involves convincing targets to convert to a radically different belief system.

\section{Research Context: The Alpha Course}

Alpha is the largest evangelizing initiative in the Western world. Its stated aim is to persuade "unchurched people" to become active Christians (Hunt 2004). The course began in a London church - the Holy Trinity Brompton - in the 1970s. It was initiated by the Reverend Charles Marnham and was originally designed to teach new church members the basic tenets of the Christian faith. In 1990 the course was taken over by the Reverend Nicky Gumbel, a former barrister. Gumbel shifted the focus of the course towards people who did not consider themselves Christians, i.e., Alpha became an evangelizing movement. He also embarked on an ambitious growth strategy that saw it become an international phenomenon. Alpha positions itself in the context of broader social processes (Hunt 2004). Specifically, it is presented as a way of helping people find "direction in a lost world" (Gumbel 2007, p. 12), a world that 
has drifted from Christianity and the values it represents to a form of materialism that emphasizes individualism and personal gratification (Miller 2008). From the perspective of Alpha, then, the institution of Christian religion has been marginalized, its dominant position in Western societies challenged by the institution of the market and the secular logic of consumption. Thus the creators of Alpha view the course not only as a way of converting people to evangelism, but also as a broader attempt to strengthen the influence of the institution of Christian religion and their particular theological take on the logic of Christianity through the recruitment of new members (cf., Pratt and Barnett 1997).

\section{The Logic of Christianity According to Alpha}

The philosophy of Alpha is located within the charismatic movement, which promotes the type of Christianity said to have been practiced in the First century AD as outlined in the book of Acts: the emphasis is on spiritual renewal and experience of the "spiritual graces" such as speaking in tongues, prophecy and healing (Hunt 2004). A notable feature of Alpha's organization is its ecumenical nature, focusing on aspects of the Christian faith that it says are shared across churches: it claims to present "the core truths of the Christian faith in a manner that every domination can get behind" (Gumbel 2009, p. 5).

Alpha's theological perspective is not accepted by many Christian churches. I conceptualize it as a particular interpretation of the logic of Christianity. This is consistent with Friedland and Alford (1991) who delineated five discrete "institutional orders", of which "Christian religion" is one. Friedland (2013) draws on Weber's notion of value spheres to make the distinction between a logic's substance and its accidental properties. From this perspective, at the core of logics are institutional substances - "the unobservable, but essential, 'value' anchoring an institutional logic” (Friedland 2013, p. 34). However, as logics are "handled" by actors they are "transformed" and "reformed" (p. 36) through practice. This may precipitate new or different meanings and practices (i.e., accidental properties) that become associated with - or grafted onto - logics and which can become institutionalized. The implication is that logics take different forms as they are practiced by groups of actors across time and space.

The logic espoused by Alpha is summarized in Table 1 and contrasted with an archetypal agnostic logic that can be said - in a general sense - to characterize the belief systems of participants prior to the 
course. At the core of Alpha's interpretation of Christianity is the idea that God works through, and is experienced through, the Holy Spirit - that in additional to physical birth, people require a spiritual birth. For the proponents of Alpha, those who "live in a relationship with God" will have eternal life, while nonbelievers cannot "enter the Kingdom of heaven" and will not therefore be saved when their biological body dies. In order to facilitate spiritual rebirth, Alpha practices a series of rituals to allow people to be "filled with the Holy Spirit". While, in the context of the course, these rituals are designed to facilitate conversion, they are practiced by adherents on an ongoing basis. For many evangelicals such practices reflect the substance of Christianity. For many other Christians, they are infused with accidental properties. It is also important to note that there are lots of other approaches that church leaders have taken to try to involve people in their churches - the Alpha course is not representative of all of the ways in which the Christian churches seek to bring people into the fold.

\section{The Structure of the Course}

While usually organized by churches, any individual or group can set up an Alpha course - leaders are volunteers (often ministers or other church members) who do not receive payment for running them. The Alpha movement is funded through the sale of course materials as well as from donations from private individuals, churches and trusts (Heard 2012). There is no fee to attend an Alpha course, although participants are often asked for a small contribution towards catering. The format and content of the courses are supposed to be standardized, although there is considerable scope for course leaders to tailor the delivery. Alpha normally lasts between 8 and 12 weeks, with participants meeting for one evening per week. Courses vary in size from just a few participants to well over a hundred. Participants are often divided into groups of around 8 including two "table leaders" who are members of the church.

A typical evening might be structured as follows. Participants arrive around $7 \mathrm{pm}$ for a pre-dinner drink. Around 7.20pm a two-course meal is served. Around $8 \mathrm{pm}$ a guest speaker talks on a pre-specified topic for around 40 minutes. The final part of the evening consists of group discussions in which the content of the speaker's talk is further explored. In addition to the weekly meetings there is a "Holy Spirit away day" towards the end of the course. This is in many ways the centerpiece of Alpha; the part of the 
course where participants are "introduced" to the Holy Spirit and when conversion often happens.

\section{Critiques of the Alpha Course}

Despite its rapid growth, the Alpha course remains controversial. Part of the controversy involves its "prescriptive charismatic slant" (Rutherford 2009) which, it has been claimed, can be emotionally

traumatic for participants. Because "experiencing God" through the Holy Spirit is such an important part of Alpha, participants may witness what many psychologists believe to be group hysteria (e.g., fainting, crying, speaking in tongues). Moreover, Alpha has been accused of prescribing a way of life to which many participants struggle to adhere (Hunt 2004). Indeed for some critics, Alpha is fundamentalist in its orientation and represents a danger to the mental health of participants. By contrast, some conservative Christian groups have criticized Alpha for, in theological terms, not being fundamentalist enough. For these critics, Alpha represents the Disneyization of Christianity, taking short-cuts with the gospel and pandering to people's desire for emotional stimulation (Foster 2006).

Moreover, while Alpha has grown remarkably quickly and attracted a very large number of participants, there is no reliable evidence on conversion rates. Indeed, internal Alpha survey data have suggested that as few as one in six participants "come to faith" (Heard 2012). In addition, it has been claimed that participants are very often active churchgoers rather than "the unchurched" (Hunt 2004). Nonetheless, many Christian churches assert that Alpha is an effective mechanism for converting agnostics and have advocated strongly for it (Brookes 2007). Certainly, there are numerous accounts of people who claim to have converted as a result of the Alpha course and it has attracted much high profile media attention. I therefore believe that Alpha offers an excellent opportunity to study the microfoundations of institutional persuasion and conversion.

\section{Data Collection}

\section{Methods}

I collected data from two main sources and two supplementary sources. First, I gathered publicly available information on the Alpha course. This included course notes and transcripts of the talks for all 15 sessions, which are designed to guide course leaders. In addition, I purchased the Alpha DVD (shown 
each week on many courses), the course handbook, and a series of course related books, the most important of which is "Alpha: Questions of Life" (2007) that summarizes the 15 course talks.

A second main source of data is 44 semi-structured interviews. Four of the interviewees were course leaders and 40 were course participants. Twenty of the 40 participants were 'persuaded' by Alpha while 20 were not. Access to 17 of my informants was obtained through personal contacts - I asked people in my social network if they knew of anyone who had taken the course, then adopted a snowball sampling technique. Access to the remaining 27 was obtained using a research company, who recruited informants on my behalf. My sample is therefore not representative of the proportion of participants who convert or do not convert as a result of the course. Twenty-six interviewees were female and 18 were male. While some Alpha participants self-identify as Christians seeking to affirm their faith, I specifically looked for informants who did not consider themselves Christians (i.e., were agnostic) prior to taking the course. Participants were asked to describe their experiences of Alpha, focusing on how they felt at different stages, and the extent to which particular parts of the course altered their views about Christianity (if at all). Thirty-six interviews were recorded. Detailed notes were taken for the other 8 .

A supplementary source of data is print media coverage of Alpha for which I used Factiva, a database of the main UK newspapers. Using the search term "the Alpha course" and the dates $01 / 01 / 1990$ to 03/03/2014, I obtained 1155 hits in UK publications. Given the volume of data, I did not code the print media coverage. However, these articles provided useful background information to support my analysis.

Finally, I use insights gleaned from my own participation in an Alpha course in 2009. Although I do not present data based on my own experience, the fact that I attended Alpha deepened considerably my understanding of it and helped me to make sense of and contextualize the information that I gathered.

\section{Data Analysis}

I divided my data into two subsets: 1) the Alpha course material, supporting resources, and interviews with course leaders, and 2) the interviews with Alpha participants. The first subset allowed me to examine the communication of messages by Alpha course leaders that is designed to persuade targets, while the second allowed me to examine the responses of targets to these messages. 
I began by examining the data concerned with persuasive communication. The analysis of these data comprised a series of steps and followed established procedures for grounded approaches to analyzing qualitative data (Charmaz 2008). I initially coded my data into first order categories through an open coding process. Consistent with prior research, the coding units were sentences or paragraphs.

Next, I looked for relationships between the first order concepts so that I could collapse them into second order themes through axial coding (Strauss and Corbin 1990). This entailed moving recurrently between the data, my own reflections and experiences on the course, and the patterns that were emerging until I was able to refine the data into conceptual categories that captured what I understood to be the core elements of the persuasive process (Eisenhardt and Graebner 2007). The second order themes are the tactics that persuaders (i.e., course leaders) used in order to convince the targets (i.e., course participants) to align their beliefs with Alpha's interpretation of the logic of Christian religion.

The final part of this stage of the analysis involved organizing the second order themes (i.e., the tactics underpinning institutional persuasion) into overarching theoretical dimensions. These overarching dimensions constituted the communication strategies used by Alpha course leaders, which I conceptualized as types of micro-level institutional work. Four dimensions emerged strongly: 1) framing work, 2) identity work, 3) affective work, and 4) performative work. The strategies and associated tactics that emerged from this part of my analysis are summarized in Table 2.

Having identified the main communication strategies deployed on the course, in a second stage I examined participants' responses to them. This consisted of three steps. First, I considered the overall outcomes of the course for participants. I initially divided them into 2 groups - converts and nonconverts. To do so, I asked all informants to compare their religious beliefs before and after the course. Informants were deemed to have converted when they indicated they had experienced a radical change in their religious beliefs following participation in the course, consistent with the 4 characteristics of the Alpha logic outlined in Table 1. I labeled this outcome conversion. My analysis indicated that 20 informants fell into this category. Informants were deemed non-converts when they indicated they had not changed their religious beliefs following participation in the course, and remained rooted in an agnostic 
logic. I labeled this outcome maintenance. My analysis indicated that 20 informants fell into this category.

However, I noticed that within the group that was labeled as having maintained their beliefs, 5 informants expressed anger and even contempt for Christian religion during various points of my interviews with them. Upon closer examination of these transcripts, I felt that categorizing these informants as having maintained their existing logic was unsatisfactory. This is because their beliefs did seem to have changed, although not as course leaders had intended: these informants appeared to have become more negative about Christian religion as a result their involvement the course (I reasoned that it is unlikely that they would have chosen to participate in Alpha if they had held such views prior to taking the course). I therefore re-analyzed these transcripts and coded the relevant parts. Three codes featured prominently: 1) anger, 2) manipulation, and 3) distancing from Christian beliefs and practices. In light of this, I relabeled the outcome for this subset of informants as alienation (codes 1 and 2) and concluded that the effect was to entrench their agnostic logic rather than to replace it with a religious one (code 3).

Next, I considered the reactions of each of the 40 participants to each of the 4 types of institutional work identified in the first part of the analysis. Specifically, I examined whether these forms of work did or did not resonate with participants. In a number of cases this was challenging: some informants were equivocal in their responses, and others actually made contradictory statements. In these cases, I made the best judgment I could on the basis of the available evidence. Where informants indicated anger or distress in response to a particular strategy, I categorized it as having induced "negative resonance" (Koopmans and Lozak 2004). The results of this part of the analysis are summarized in Table 3.

Finally, I sought to shed light on the factors that led to the three outcomes that I identified (conversion, maintenance, alienation). This involved comparing and contrasting across transcripts and looking for recurring themes in my data. I first considered the factors that influenced the resonance of the 4 types of institutional work required for conversion. I then considered the specific factors that led to maintenance, focusing on why leaders' institutional work did not resonate. Lastly, I tried to understand the distinctive factors that underpinned alienation. The outcomes and associated factors that emerged from this part of my analysis are summarized in Table 4. 


\section{Findings}

In the first part of the analysis I explore Alpha from the perspective of the persuaders. I found that the process of persuading actors to align their beliefs with an institutional logic is underpinned by 4 main communication strategies that I conceptualize as types of micro-institutional work: framing work, identity work, affective work, and performative work. Importantly, there was a temporal dimension to these strategies: I found that framing work and identity work were predominant in the first part of the course, with the emphasis shifting to affective work and performative work in the later part of the course.

\section{Framing Work}

As we would expect from the existing literature (Kellogg 2011; Lammers 2011; Scully and Creed 2005), one communication strategy that I identified concerns the breaking and remaking of generalized myths about an institution, for which I use the term framing work from social movement theory. Thus a core part of Alpha's persuasive efforts involves sending messages that directly address what Alpha constructs as negative perceptions of the church and offering a different view. More specifically, I identified two tactics that unpinned this process, namely confronting stereotypes of Christianity, and using legitimate actors to promote messages in order to reinforce a different perspective on Christianity.

Confronting stereotypes. This tactic is similar to the idea of diagnosis in social movement theory (Snow 2007) as well as the notion of sensebreaking (Pratt 2000). Thus the Alpha course begins by presenting a set of stereotypes about Christianity in the UK, and then imparting an alternative view. Mainstream forms of Christianity are portrayed as lackluster, reserved, and lacking in energy. For example, the course notes for the introductory Alpha talk contain the following vignette (page 2):

I thought it [Christianity] was boring. I found everything about Christianity, religion, the church, so dull! I had sympathy with something that Robert Louis Stevenson once entered in his diary as if he was recording the most extraordinary phenomenon. He wrote this: 'I have been to church today and am not depressed.' That was my reaction - I found it so dull.

From the perspective of Alpha, the image of Christianity in the UK has been damaged by young people's poor experiences of church at school or Sunday school, with worshipers subjected to dry sermons, old-fashioned hymns, and prayers to which they cannot relate - too much passive listening and 
not enough active engagement. Moreover, much worship in Britain is depicted on the course as overly prescriptive, designed to conceal emotion rather than to harness and celebrate emotion:

I was brought up to suppress emotions, basically, from quite an early age...But I think a lot of it is just Britishness! And Jesus, you know, was not British! I mean, that comes as quite a shock to some people! But he wasn't (Course notes talk 10, p. 13).

Having presented these stereotypes, course leaders proceed to challenge them and to suggest that "true" Christianity offers something different. The stated aim is to broaden the appeal of Christianity. For example, the settings in which the course takes place tend to be carefully chosen. Some are held in restaurants or at people's homes, while churches that host Alpha are often laid out more like cafés than places of worship. The mode of interaction is also informal, and designed to reinforce the message that Alpha represents a different kind of Christianity. Thus by placing participants in an interesting setting and interacting with them in an engaging way, Alpha seeks to alter immediately participants' preconceptions.

However, there are other more explicit attempts to challenge what Alpha sees as the generalized perceptions of Christians and Christianity. Consider the following quotation from the Alpha course notes: So [being a Christian] is not just about having some 'great feeling'; it's about going out and making a difference in a world that so desperately needs transformation... It's not easy. But nor is it boring. It's not untrue. It's not irrelevant to our lives. It's exciting, it's true, it's relevant: because Jesus said: I am the way and the truth and the life (Course notes talk 1, pp. 13-14).

More broadly, Alpha course leaders are open about their aim to expose participants to a different kind of Christianity. "Evidence" is presented for the existence of God, with the central message being that the church is about encountering "the power of God" through the Holy Spirit - leaders argue that it should be an inspirational and energizing experience that imbues adherents' lives with new meaning.

Using legitimate actors to promote messages. A second tactic used to reshape what are presented as generalized myths about Christianity is to draw attention to Christians with high levels of legitimacy in order to reinforce the potency of the messages. Two types of actors are highlighted. The first is high profile Christians, often from the arts, music or film. Stories about their journey to faith are particularly prominent. For example, an account from Bono (lead singer of Irish rock band U2) detailing the moment that he claimed he understood the meaning of the Christmas story is sometimes used. Other high profile 
Christians about whom anecdotes are invoked include Irish singer Sinead O'Conner, writers H.G. Wells and C.S. Lewis, and actor David Suchet. The message being communicated through these accounts is unambiguous: here are successful people who may be role models for many of you; if these individuals are guided by Christianity then surely there must be some substance underpinning it.

The second type of actor used to legitimate Alpha's interpretation of core Christian beliefs and practices are 'ordinary' people, usually members of the church hosting the course, who give their “testimonies" - accounts of their journey to faith - throughout Alpha. The guidelines for course leaders are explicit about the role of such testimonies. For instance, the notes accompanying the introductory talk state that " $[\mathrm{t}]$ he most effective testimonies are ones that refer to your life before you were a Christian and how you came to realise that it was true so that non-Christians may relate to it better" (p. 2). Similarly, during the session on "Does God heal today?" course leaders are encouraged "to tell an inspiring story or find someone with an inspiring healing testimony to raise faith as you end the talk" (p. 18).

The Alpha course material even gives example testimonies, which the course notes recommend course leaders reword or elaborate upon based on personal experiences or the experiences of church members. These testimonies are designed to be compelling, and often involve previous Alpha participants.

\section{Identity Work}

Consistent with the institutional literature (e.g., Kellogg 2009; Mohr and Guerra-Pearson 2010; Rao et al. 2003), a second communication strategy underpinning institutional persuasion involves purposefully building a sense of community and solidarity, which I term identity work. This entails two specific tactics. The first is promoting a shared sense of identity at a micro-level, both amongst participants and between participants and course organizers. The second is linking macro-level frames to the level of the group by encouraging participants to feel part of a global movement.

Promoting a shared sense of identity at a microlevel. A notable feature of contemporary evangelism, particularly in the US, is that it often involves large scale events held in venues such as sports grounds that can accommodate thousands of people. By contrast, Alpha adopts an approach that relies on a setting designed to be intimate, with a particular emphasis upon social interaction. The explicit intention 
is to establish a set of rewarding relationships in order to enrich the experiences of participants and create an affinity with the host church that provides an incentive to remain involved after the course.

More fundamentally, this aspect of Alpha appears designed to build a sense of shared identity amongst participants. The course projects the idea that participants are on a "journey" to discover the meaning of life to facilitate the transition from non-believer to believer. Partaking in singing and other rituals - discussed in more detail below - emphasizes that Alpha is a group, not an individual, endeavor. The main focus of this identity work, however, takes place in the small group setting that is a key feature of Alpha. Groups may comprise around 8 people, including 2 table leaders. Course organizers sometimes place people with relatively similar backgrounds in the same group, perhaps to facilitate this process of identification. The importance of the small groups is highlighted throughout the course. For example, the course notes for the session "What about the Church?" contain the following passage:

...one of the things that I find so amazing about the small groups...is... how quickly people begin to drop their barriers and people start to talk openly about things that are real. There's this kind of authenticity... And often in the world relationships can be quite superficial, but in a small group, even though we've only known each other for quite a short time, there's a depth of friendship that develops... there's respect for one another; where we listen and learn, we eat together, we learn together, pray together (p. 7).

Linking macro-level frames to the level of the group. As well as trying to forge a shared identity at the level of the group, course leaders inform participants of a huge Christian movement eager to welcome them. The following figures are sometimes quoted: there are around 1.9 billion Christians in more than 270 countries representing 34 per cent of the world's population. Statistics on the number of people who become Christians in China every day and the proportion of the population who attend church in various African countries are also given. While leaders acknowledge that church attendance has been declining in the UK, a core message is that there are signs of renewal and reasons for optimism about the future.

A particular emphasis is placed on the notion of a "Christian family." One course leader said that an important gift of the Holy Spirit is its capacity to help Christians "develop a liking" for one another, adding that it is "not possible to be an isolated Christian." The notion of a shared identity through the metaphor of family is also emphasized by Gumbel (2007, p. 136-7) in his extended course handbook: The same Holy Spirit lives in every Christian... If people have the Spirit of God living within them, they 
are Christians and our brothers and sisters. It is a tremendous privilege to be part of this huge family...

There is a closeness and depth of relationship in the Christian church that I have never found outside of it.

In addition, participants learn about a UK Christian sub-culture that, for those who do not belong to it, is largely invisible - for example, a Christian music festival called Momentum that is "like Glastonbury for Christians" and attracts 18,000 people annually, Soul Survivor, an NGO that organizes various events for young Christians, and Spring Harvest, an evangelical gathering which attracts around 55,000 Christians each year. Again, the idea being presented is that through Alpha and the church one can become part of a movement with a clear identity and purpose.

Thus by linking macro-level frames to the level of the group, leaders seek to provide targets with a sense of belonging, and to legitimate the beliefs that underpin Alpha's perspective on Christianity. This subtly promotes a distinction between an in-group and an out-group (i.e., Christians and non-Christians).

While the literature would have led us to expect framing work and identity work to play a key role, I also found evidence for 2 other kinds of work that have not been extensively studied in the institutional literature: affective work and performative work. In the following subsections I consider these in turn.

\section{Affective Work}

A third communication strategy that I identified as underpinning institutional persuasion is the strategic use of emotion, which I term affective work. Two emotions are particularly prominent. The first is empathy, which is used by course leaders in an effort to show the relevance of Alpha's view of Christian religion to contemporary society. The second is guilt, which is used to legitimate particular moral assumptions associated with Alpha's interpretation of the logic of Christianity. Both emotions feature prominently in psychological research on persuasion (Hibbert et al. 2007).

Eliciting empathy. An important tactic used by Alpha course leaders to persuade participants to accept its theological perspective is to exhibit strategically empathetic understanding. This appears designed as a way of constructing a need for evangelical Christianity among participants and society more broadly. At the same time, it serves to undermine what are presented as the dominant secular logics of consumption and materialism. More specifically, a prominent theme is the intrinsic desire for meaning 
and the extent to which this desire is enabled or constrained by contemporary social structures. This theme comes through especially strongly in the testimonies that are punctuated throughout the course.

The account given by a course leader illustrates this point. He tells participants that he knows how it feels to have troubles in life. He did not become a Christian until his late 20s, by which time he was in a serious predicament - he had become involved with drugs, gotten his girlfriend pregnant, and suffered a serious break down. He said he felt that his life was without purpose and direction; he was making decisions he knew were wrong but could not change course. He claims his life was altered irrevocably when he began to read the bible, which allowed him to make sense of the world and his place within in it.

In addition to these testimonies, speakers and course leaders ask rhetorical questions about whether participants feel fulfilled and disclose times that they have struggled to make sense of their own lives. For example, the introductory session focuses on how to find "direction" and the "hunger for meaning and purpose" that is said to exist within human beings. It also suggests three questions that everyone should ask themselves: "What am I doing on earth? What is the point of life? Where am I heading?" (Alpha Course Manual 2009, p. 4). These questions form the basis of discussion during the small group sessions. This discussion often focuses on traumatic events such as bereavement or the breakdown of relationships.

It appears the idea being advanced is that a lack of purpose and meaning is endemic in Western society. This allows course leaders to empathize with the apparent sense of emptiness felt by many, and to suggest that these problems are rooted in a lack of engagement with the church:

You and I were created to live in a relationship with God. Until we find that relationship there will always be something missing in our lives. As a result, we are often aware of a gap... A housewife... wrote of a 'deep, deep void'. Another young girl spoke of 'a chunk missing in her soul' (Gumbel 1991, p. 4).

Course leaders argue that non-Christians try to fill the emptiness that they feel through a range of activities: making money, consumption, career, sport, music, sex, or alcohol. However, while providing short-term gratification, they "do not satisfy that deep hunger inside every human being" (Gumbel 1991, p. 5). My interpretation of this tactic is that, by suggesting we live in a damaged society, that such a society underpins the feelings of emptiness and loneliness that everyone experiences at various points in life, and by empathizing with these emotions, course leaders are seeking to present evangelical 
Christianity as a 'solution' for a range of challenging issues at both an individual and societal level.

Promoting guilt. A second way in which course leaders seek to use emotion strategically is through guilt arousal. Most obviously, leaders seek to arouse guilt simply by asking participants to consider times they have sinned. This shines a light on targets' past behavior and encourages them to acknowledge actions of which they are ashamed. Participants might also be asked to consider times they have been sinned against, and whether they have forgiven those who have inflicted harm on them. Bearing a grudge or malice against the perpetrators of a perceived injustice long after the event might indicate shortcomings in behavior as well as an element of hypocrisy in interactions with others. Having established that everyone sometimes falls short of the behavior to which they aspire, participants are then offered concrete steps for guilt reduction - by admitting their transgressions and asking for forgiveness from God participants are promised "salvation" from the power of sin.

Guilt, sin and forgiveness are common themes throughout the course, but they also form the sole focus of a session entitled: "How can I resist evil?" In this session participants are told that the Devil is clever and cunning, and that at some time in their lives everyone can be classified as a sinner: "Virtually

all of us have something in our lives of which we are ashamed" (Gumbel, 2007, p. 163). This more candid form of guilt arousal is accompanied by more structured and detailed guidance for guilt reduction, which is framed as "practical tips" in the course manual. These "tips" include prayer and "harnessing the power of the Holy Spirit" (Alpha Course Manual 2009, p. 66).

\section{Performative Work}

The final communication strategy that I identified is the strategic use of performance and ritual, which I term performative work. I concluded that this comprises two main tactics: producing a theatrical spectacle and enabling theatrical participation. Specifically, I found that Alpha constitutes a performance that is designed to convey and legitimate the system of meaning that underpins its interpretation of the institution of Christian religion (cf., Alexander 2004; Turner 1969).

Producing a theatrical spectacle. Although Alpha focuses on a range of serious topics such as the nature of sin, death, and the meaning of life, in many respects it is impressive theatre: it is designed to 
entertain as well as inform with leaders putting on a show to get their message across. More specifically, my analysis suggests that course leaders rely on two key theatrical mechanisms: humor and storytelling.

The role of humor quickly becomes clear from analysis of the course material. Gumbel's first talk on the Alpha DVD begins immediately with a joke about the decline in church attendance in the UK being so dramatic that even God has left the Church of England. The remainder of this and subsequent talks are peppered with further jokes and light-hearted stories. Indeed, the course notes for leaders emphasize the importance of humor at key points in all of the sessions. The intention, presumably, is to set the tone for the course and to illustrate that part of the purpose of Alpha, and indeed of Christianity, is to have fun.

In addition to humor, storytelling is frequently deployed by course leaders and speakers. Stories represent a device to entertain and engage the audience, but they also convey a distinctive system of meaning and are designed to legitimate particular beliefs and practices. The stories told on Alpha are typically brief and quite simple in their structure. They tend to feature the narrator or 'ordinary' people as protagonists in an effort to help the audience relate to the narrative. They also appear designed to provoke some kind of emotional reaction. Although storytelling features throughout the course, it is a particularly prominent part of the session entitled "Does God heal today?" The following story taken from the course notes from this session neatly illustrates the strategic use of storytelling on Alpha:

I remember meeting here a woman...who was in her sixties. She was from Cwmbran in Wales...And she told me what had happened. She said 'Sixteen-and-a-half years ago', she said, 'I went blind.' She had an infection which had eaten away the retinas and mirrors behind the eyes, and apparently they cannot be replaced. So she had a white stick, and she had a guide-dog - I think the guide-dog's name was Tina. And she was in a lot of pain, actually. And in her local church in Wales she went on an Alpha course. She went on a Weekend, and during the Weekend she experienced the power of the Holy Spirit in a way she'd not experienced before. And the amazing thing was that the pain that she had been in for all those years just went. And she was so thankful to God she went to church that night to give thanks to God. And... the minister in her church said he would like to anoint her with oil as a sign of this healing that had taken place over the weekend. And he anointed her with oil. And as she wiped away the oil, she looked up, and she could see the communion table in front of her. She went home that night, and she said it was amazing, because she had not seen her husband for sixteen-and-a-half years (Course notes talk 13, p. 13).

As well as being a compelling story, this narrative is designed to convey the power of the Holy Spirit that - according to Alpha - can heal those that are consumed by it. Moreover, this and other stories are often told in an emotional way, sometimes accompanied by tears and often with the voice breaking. 
Enabling theatrical participation. In addition to putting on an impressive theatrical spectacle for participants to watch, the course encourages participation in the spectacle itself via a series of rituals. For example, many courses invite participants to sing Christian songs. On larger courses musicians appear on stage at various points, with the words displayed on plasma screens. As the course progresses, course leaders invite participants to join them in prayer. Towards the end of the course participants are given the opportunity to be "healed" by a spiritual healer who offers to "lay hands" on people with ailments (physical or psychological) in an effort to cure them. However, the most intense part of Alpha with the greatest emphasis on theatrical participation is the "Holy Spirit away day" that happens on a Saturday during the second half of the course. Its purpose is to teach participants about the Holy Spirit as described in the book of Acts, and ultimately to ask them to invite the Holy Spirit into their lives during a ritual at the end. The away day, and Alpha as a whole, is designed to reach its climax during this ritual. The intention is to allow participants to "experience God." It is the point at which conversion often occurs.

Participants are told that the Holy Spirit brings with it a series of possible gifts. For example, it might bring wisdom, the power of healing, miraculous powers, or the power of prophecy. A focus of discussion in the early part of the day concerns the gift of speaking in tongues. Participants are informed that although not everyone receives this gift, and those who do not receive it are not "second-class Christians" (Course notes talk 10: 18), it is often one of the first gifts that people encounter. To experience the Holy Spirit participants are advised that they need to get rid of anything that might block it, and to overcome their fear of what might happen to them. Moreover, they need to make a commitment to change and be forgiven - internet addiction, sexual sin and jealousy could all prevent the Holy Spirit from entering.

While there is variation in how this ritual is conducted, one structure is as follows: The ritual gets underway with a song entitled Consuming Fire that is about "abandoning" oneself to God. At the end of the song a guitar player continues to strum. The course leader asks anyone who wants to be prayed for to leave their seats and stand at the front. Those who go forward are asked to "open your hands and faces to heaven." The course leader says a prayer in which God is asked to release the gifts of the spirit. At this point, some of the course helpers and participants begin speaking in tongues, getting gradually louder and 
louder as the course leader continues to call for the release of the gifts of the spirit. Next, the guitar player sings the words "I surrender unto you, I surrender unto you..." At the same time the course leader shouts "release, release, release [the gifts of the Holy Spirit]," clapping his or her hands each time. At this point, the team of course helpers begin praying for those who have gone forward. Sometimes participants burst into tears, others fall to floor, and a sense of apparent hysteria envelops the room. Finally, the Lord's Prayer is said and the ritual ends.

\section{Message Resonance and Target Outcomes}

In the second part of the analysis I explore the Alpha course from the perspective of the targets. Specifically, I consider the extent to which each of the strategies outlined above resonated with targets and the combined effects on targets' belief systems. My analysis revealed three distinct outcomes. The first is that targets change their belief system and internalize a new institutional logic; i.e., they convert to evangelical Christianity. The second is that the institutional logic held by targets prior to the course is unchanged; i.e., they maintain their agnostic logic. The third is that targets develop negative views towards the logic being promoted; i.e., they become alienated from Christianity. For each outcome, I looked for patterns with respect to the extent to which the four strategies resonated (see Table 3) and for the factors that underpinned the three outcomes (see Table 4).

\section{Conversion: The Internalization of a New Institutional Logic}

The first outcome, experienced by half of my 40 informants, is conversion to Alpha's interpretation of the logic of Christianity. My analysis suggests that such an outcome requires that all four communication strategies resonate with targets. In other words, should any of the strategies fail to resonate, the persuasive process will fail and conversion will not occur. With regard to framing work, I found that two main factors promote resonance. One is the perceived consistency of the messages being conveyed.

Interestingly, it appeared that message consistency was more likely when course leaders gave ambiguous responses to key issues that left room for interpretation rather than claiming that particular views were "right" or "wrong". This insight is succinctly captured in the following response from an interviewee: The leaders weren't trying to trick us into answers. There was a... very sincere amount of dialogue 
about... the bible, about the value of prayer... and I have to say that I found it helpful because I thought I'd go there and get some very glib answers but quite honestly they weren't... [The course leaders] actually said, "well we don't know [the answers] but we think that this might help you. And I'm much more taken by that than someone who says, well, the bible says this and you must believe."

Other converts stressed that leaders tended to involve participants in developing answers to questions - albeit within a narrow set of boundaries - instead of imposing their own views. Thus rather than simply taking the role of passive listeners, this group of participants felt that they were involved, at least to some extent, in a shared endeavor to construct meaning:

Whatever you threw at them [the course leaders] they always seemed to have a logical explanation. And, you know, it's like blind faith a lot of the time and you know that there isn't an answer because it's about faith... People raised all sort of issues, like why does God let all these awful things happen to people. But the leaders I think held things together really well and between us all we tended to thrash out an answer.

In addition to the content of the messages, a second factor that promoted the resonance of framing work was the perceived charisma of the communicators. Indeed, it was clear from the interviews that participants were more likely to engage if they found the course leaders to be compelling in their message delivery and style, and if they were admired or even idolized by targets:

The chap that was leading [the course] was one of the most inspirational people I've ever met. An ex SAS commando that served 10 years in the SAS... then once he left the army he got himself a job as a magician believe it or not... touring the world with Formula One... His stories, his conviction, the way he was open to any questions... you could say he definitely changed [the way I saw the world] overnight.

Similarly, many converts said that they altered their perceptions of evangelical Christianity partly because of the energy exuded by course leaders. For example, one participant told me that she felt comfortable from the moment she stepped into the church at the start of the course:

The first day that I went on the course, I felt like... they [course leaders] were very, very warm, natural great people... The first few times I felt like I was in... a very nice warm place... At that time I was having personal problems and was very confused and it was a good thing to be with people like that.

With regard to identity work, the main factor that appeared to influence resonance was a perceived connection between the targets. Many respondents were struck by how their group began to share intimate stories about various aspects of their lives even though members did not know each other very well, and said that this had resulted in a strong sense of community. Some course leaders attempted to place together participants who were similar in terms of age, gender, and/or social background, while on other courses the process appeared random. My data suggest that grouping participants on the basis of 
demographic characteristics was not necessarily effective. This is because participants connected most strongly on the basis of shared experiences - such as illness, bereavement and divorce - which transcend such characteristics. Interestingly, I found that sometimes course leaders needed to do only very minimal identity work; a number of participants identified "kindred spirits" simply by having the opportunity to speak with them in an environment in which they felt comfortable "opening up":

We gelled straight away so I think that there's the safeness there, because you feel vulnerable if you're opening up don't you, and speaking about your feelings... some people have had really difficult lives. But I think just to feel safe in that place or that environment, and they're building up relations with you but at the same time sometimes they don't realize the relationship they're building up with God.

My analysis suggests that, although the two strategies enacted during the first phase are a prerequisite to conversion, they are not sufficient in and of themselves. Specifically, I found that while framing work and identity work, when successful, deepen targets' engagement with the persuasive process, their core beliefs at this point are unchanged. However, this group of targets is sympathetic to the ideas being promoted as they enter the second phase of the persuasive process. And if the communication strategies used during the second phase (affective and performative work) resonate, targets adopt a new institutional logic and the persuasive process is successful; i.e. conversion occurs.

With regard to affective work, I found that the key factor that promoted target resonance was the ability of persuaders to regulate target emotions. For example, many of those who converted talked about how course leaders were able to empathize with them by constructing the notion of a "void":

Most of us have our daily problems don't we and have parts of our lives that we think are missing... at the time... you know externally you'd think... everything [was] in place for a happy life, but [I realized] there was definitely something missing in my life.

The concept of sin was a more challenging topic for course leaders and participants to grapple with, particularly the idea of damnation. However, in many instances leaders were able to construct subtly a sense of guilt amongst participants without them feeling that their emotions were being controlled in a cynical way. The result was that a subset of interviewees accepted the idea that everyone needed to become active Christians and to believe in God in order to be "saved". For these participants, conversion through Alpha became a catalyst for them to "spread the Word", particularly to family and friends: 
The fact that Jesus died for our sins is so, so powerful and Alpha helped me understand what he did for us... It was done very sensitively, they [the course leaders] just put the ideas out there, and it was up to us to make sense of them.

On other occasions, informants reported that course leaders toned down the rhetoric on damnation, and engaged less forcefully with this difficult topic:

I thought that I'd be told if I didn't repent I'd end up in the burning fires of hell, because that's the message you hear on street corners from those who shout about their faith... But they kept it very light and kind of let the questions flow. It was very much... "I bet some of you are thinking that..." There was one lady who... had issues with what we'd perceive to be evil. Someone else had issues with healing... But [the course leaders]... made the effort to actually get to know us, therefore we were more willing to listen. It's like anything... if someone gives you the time you give them the time back.

While all strategies were required to resonate for the persuasive process to be successful, performative work appeared to be the strategy most likely to trigger conversion. While conversion sometimes happened during one of the major rituals - the healing or Holy Spirit rituals - in almost half of cases it was actually a period of days or even weeks after the course had finished that participants converted. This is consistent with the notion of the "sleeper effect" (Hovland 1959) that has been identified in psychology. In other words, while a message may not resonate, or only partly resonate, when it is first conveyed, it can eventually become resonant as targets reflect upon and process its content.

Nonetheless, regardless of whether they converted to evangelism during or after the course, all 20 converts were sympathetic to the idea that God's presence could be experienced through such rituals, and all believed they had been touched in some way by the Holy Spirit during and/or following their participation in the course. The experience of the Holy Spirit might take the form of a loss of physical control, but often manifested itself simply in a sense of peace and increased confidence. For example, one interviewee told me that prior to the Alpha course she used to break into spontaneous crying:

It was proper full on sobbing, not just a few tears trickling down my face. It would start like that but then would be... you know... really emotional crying. I don't know how to describe it... I suppose the sort of crying you'd do at a loved one's funeral, at that kind of level... I found it quite distressing because I didn't know why it was happening and I felt kind of stupid to be honest.

However, after being "touched by the Holy Spirit", she said that these random bouts of hysteria stopped, and she claimed to have found a calmness that allowed her to build emotional resilience: It's really difficult to put into words actually. It's just like... almost like an electrical current running 
through your body... you're sat there with your eyes closed and then when you open [them] it just feels brighter. Everything seems brighter and you know like my whole body felt like it had been aerated... All the negativity had moved on, or out of me.

Another informant explained how his experience of the healing ritual played a key part in his conversion. He had been very ill and in a lot of pain. Even though his illness was not cured following the ritual, the physical sensation that he felt during it had a profound effect upon him:

The course leader was standing down at the front of the church and he says, if anybody is feeling ill or troubled at the moment you can stand in this circle and we'll lay hands on you. I [was] not feeling well and I'm quite skeptical about all of that to be honest with you... anyway I'm not feeling so good so I [thought] I'll go down and try this. So I went in the circle and everybody placed their hands on me. And the last person did it and I began to get warm. Not unnaturally warm, just warm - good warm. And then I felt a sensation... kind of like maybe smoke rising from your feet and travelling right through you. I didn't understand what it was and I came away a bit nonplussed to be honest. And I met the minister later and I said I've never quite experienced anything like that in my life. He said: did you get warm? I said yes I did, and that was all he said... It was evidence of Jesus' presence to me... I've received enough evidence [through the ritual] to endorse my faith that there is definitely something beyond us, definitely.

It is difficult, given the nature of my data, to capture precisely why performative work resonated in some instances and not in others, particularly given the diversity of targets' experiences. However, my interpretation is that the most important factor is the perceived authenticity of the performances. In particular, the two high intensity rituals - the healing and Holy Spirit rituals - are extremely complex. They are of course scripted to an extent, but the scripts need to have significant flexibility built in to them. The fact that there are multiple actors involved in the rituals - more than 100 people on larger courses adds to the complexity. Orchestrating such a cast, and creating the type of "ecstatic worship" these rituals involve requires that targets grant persuaders a particular type of charismatic authority. Several converts commented on the choreography of the rituals and the role of the course leaders in conducting them. Moreover, I was struck by the fact that converts' description of the nature of the rituals was often different from that of non-converts. Specifically, converts were more likely to have participated in rituals that were more elaborate and dramatic than non-converts. Of course, this may be partly because the rituals had a much greater impact on converts and so their recollection was more vivid, but it nonetheless suggests the enactment of the performance plays a critical role in the effectiveness of the rituals.

\section{Maintenance: Logic held by Target Unchanged}


A significant proportion of informants (15 of 40) left the course with their belief system essentially intact. In considering this outcome, my data indicate two possible explanations: participants' openness to the messages communicated on the course, and the skill of course leaders in communicating the messages.

First, this group of informants may have been less open about the possibility of conversion from the outset - while all informants chose to participate in Alpha and said they were amenable to the idea of conversion when they began the course, in reality their initial openness to the core messages being promoted by Alpha appeared to vary. For example, one informant told me that she attended the course in part because her husband, a committed Christian, had asked her to attend. Another said that she participated partly because she thought that it would improve the likelihood of her child being admitted to her local (church run) school. A third participated in part because her children were friends of the vicar's children, but admitted she was skeptical from the beginning:

I wasn't keen to go to be perfectly honest. It wasn't at a time that suited me... But the vicar... is quite persuasive... and then some friends of mine were doing it and they sort of said "come along, we'll have fun because we're going as a group... even if the actual Alpha bit isn't for you". We didn't know how it was going to turn out but we thought we'll get out of the house a bit, get away from doing bedtime with small children... [the vicar] is quite young, he's a father at the local school as well as being a vicar...I went along because I thought... well it's a chance to...spend some time with my friends.

It is important to emphasize, however, that several converts told me they were deeply skeptical about Alpha prior to taking it and I did not discern a clear pattern linking motivation to outcomes. Thus while I concluded that participants' motivation for attending the course, and more specifically their openness to the messages being promoted, is likely to influence the probability of conversation, the methods that I adopted and data I collected do not allow me to make unequivocal claims in this regard.

A second explanation, which is supported more strongly by my data, is that the leaders who led the courses attended by this subset of informants were less effective in communicating the core messages underpinning Alpha. However, it is important to note that, as indicated in table 3, there is variation within this group in terms of the extent to which particular strategies resonated. Specifically, this set of informants could, broadly speaking, be divided into three groups. A first group actually exited the course before the end. For these participants, neither the framing nor the identity work resonated - they lost 
interest and did not complete all of the sessions. For example, one informant told me that even though a close friend invited her to Alpha, she struggled to relate to and communicate effectively with the course leaders. She also felt that the course leaders and other participants seemed "different" to her (i.e., identity work was ineffective). As a result, she decided to leave the course about two thirds of the way through without taking part in any of the rituals. She acknowledged that Alpha had been a source of comfort for others on the course, but said her feelings about Christianity were unchanged:

I thought... you know you get home from work, you don't want to be spending a chunk of an evening going to [Alpha]. You know, I'd rather come home and cook my own meal to be honest and share it with my husband than 8 to 10 other people...I don't know...I guess I was looking for that sort of friendship and sort of an extended family, I just don't feel I achieved that through the Alpha course at all.

A second group completed the course and claimed to have enjoyed it, but seemed to have made up their minds during the first phase that they were not going to convert to evangelism. For this group, either framing work and/or identity work failed to resonate. While they continued to phase 2 , they chose not to participate in the core rituals and tended to take the role of detached observers. For example, one interviewee explained that, while he felt a strong connection with others on the course (i.e., the identity work appeared to resonate), he was left unsatisfied with how course leaders responded to his questions about the nature and core beliefs of Christianity (i.e., framing work was ineffective). Specifically, he perceived their arguments to be incoherent and based on faulty logic that constituted "blind faith". While he completed the course, he said he realized that he was unlikely to convert very early on:

I made...friends out of it. I mean there's people that did the course that I still see in town... And you know I look after one of the lady's dogs every now and then...but... what I found on my journey of trying to get into Christianity is there's so many questions that could go on forever, that's the thing. So if I was to say something within the group, and... someone would come back with an answer, it was never an answer I was entirely satisfied with, it didn't... clear up any of the objections that I had to it, that's the thing.

A third group was particularly interesting. For these participants, framing and identity work appeared to resonate, and their engagement with the course seemed to have increased following its first phase. This group did participate in the core rituals, but even though they "wanted" to convert, felt unable to do so.

For example, one informant said he decided in advance of the away day that he would take part in the Holy Spirit ritual, but that during the ritual he felt unable to "commit". He said that most of the people on 
the course he attended were already Christians seeking affirmation rather than conversion. From his perspective, the ritual was designed for people who considered themselves part of the church rather than for people like himself who were looking to convert (i.e., performative work was ineffective):

I think I was the only who didn't go forward because I had these doubts...And it was easy for everyone else to walk forward because they were committed...they were getting reassured of what they already believed and they were just glad to walk forward...I could have walked forward and said 'well maybe this has changed me', you know?... But I didn't... What I felt was that these people were ready for it, they were ready to give 100 per cent and I wasn't. I know it's a selfish thing to say. It's just that it was, to me, telling a lie... kidding all these people on by going forward with them, or [should I] be brave and don't go? And it was a struggle, it was a real struggle because I got a lot out of the course.

\section{Alienation: Logic Held by Target Becomes Entrenched}

For 5 of the 20 informants who did not convert, my analysis suggests a distinctive reaction. Specifically, rather than simply being unconvinced by the persuasive strategies offered by Alpha and maintaining their existing belief system, these informants became alienated from the Alpha logic that was being promoted and developed a hostility towards it, which had the effect of entrenching their existing logic.

Interestingly, these informants experienced the course in quite a similar way: in all 5 cases they continued to the second phase of the course as engaged participants (both framing and identity work resonated), but reacted negatively as the intensity of the course increased. Their negative reactions appeared rooted in their experiences of the affective and performative elements of the persuasive process, which for some was akin to manipulation or even deception (i.e., they resonated negatively). Thus I conclude that two factors appeared to underpin this outcome: 1) investment in the persuasive process on the part of targets, followed by 2) a perception of manipulation. The result is that some participants who go through phase 2 as engaged participants but who are not persuaded risk becoming disaffected with the logic being promoted and to view it in a more negative light than they did prior to the course.

With regard to affective work, many of those who were alienated could relate to the feelings of emptiness articulated by course leaders. Most were motivated to attend the course because they felt that something was "wrong" in their lives. However, some reacted very negatively to the emphasis on sin and in particular to the notion of damnation - being told that they and their family would "go to hell" if they did not dedicate their lives to the service of God. These informants frequently stated that knew many 
"bad" Christians, but many "good" people who were not Christians. Others felt patronized; that they were being "preached to" and their lifestyle judged. One participant recounted an argument he had with a course leader who told him he faced damnation if he did not become a Christian:

... then my question after that was, oh so Adolph Hitler killed how many Jews in the Holocaust, so right before using his bunker in World War II, in the last days of his life, he shoots himself and decided to accept Jesus and God and all that, and... he's going to get to heaven? And... the course organizer said, 'yes, that's right'... he's been forgiven'. I said ok that's fine, when I get to my last day and I still don't accept wholeheartedly the word of God I will forever be a sinner and won't go to heaven, even though I'm essentially a decent human being... that led to an impassioned plea [from the course leader] that I should open my heart [to God] or whatever... so I did feel very much like I was being judged.

With respect to performative work, Alpha's low intensity rituals such as storytelling, prayer and singing did not generate significant adverse reactions amongst this group. However, when it came to the two high intensity rituals (the healing and Holy Spirit rituals) reaction ranged from deep unease to anger. Indeed, in some cases these rituals appeared to turn this group decisively against not just the charismatic interpretation of Christianity that underpins Alpha, but Christians and Christianity more broadly. A recurrent theme amongst this set of interviewees was a feeling that they were being manipulated. For example, one interviewee described course leaders' attempts to heal a pain in her chest. Not only did the pain persist, but she found the "healing" process traumatic:

They made me feel like I was evil. They put hands all over me trying to get the spirit out of me... They were saying all weird stuff, I can't remember now even what they said, but it made me feel, like, dirty... or needed cleansing. I was really upset so I was like, I've had enough of this.

Similarly, the reaction of some of those who participated in the Holy Spirit ritual was very negative. The rationale underpinning this ritual, presumably, is that given the magnitude of the change being asked of participants, many would choose to do nothing without some kind of impetus. The risk, of course, is that targets become cynical. Indeed, by asking Alpha participants to make an explicit choice, and to do to in full view of other course members, an in-group and an out-group are inevitably created:

I felt very uncomfortable on the away day, the music playing, the guitar playing, the atmosphere building up, people being entreated to walk out to the front. I thought people were being driven into a heightened state of emotion... I found the whole thing a bit disturbing and uncomfortable. It's not for me - I don't do that. Different people approach these things in different ways, but I'm not sure I'm that sort of person.

Thus while my study emphasizes the critical role of affective and performative work in institutional 
persuasion and conversion, it also shows the potential unintended consequences of these strategies: while they may wield tremendous persuasive power, they can also generate intense anger and resentment that are counterproductive to persuasive efforts and may result in alienation from the core ideas being promoted. The skills required to execute these strategies are considerable, and targets may offer alternative or competing interpretations of particular messages and events. Indeed, the reactions of this subset of Alpha participants highlight the volatile nature of the persuasive process, and shows that efforts to persuade, regardless of how well designed, are very unlikely to result in conversion in all instances.

Friedland's (2013) work on institutional logics helps deepen my explanation for this finding. He makes the distinction between a logic's substance (its essential value) and its accidental properties (meanings that come to be associated with logics through practice). The alienation-entrenchment dynamics I uncovered may be rooted in targets' conflation of the Alpha logic with a singular logic of Christianity. For example, for adherents of Alpha, the insistence that people who do not become confessing Christians are denied admittance to Heaven and cannot be "saved" is an essential part of the logic of Christianity, while for many other Christians it is an anathema - an accidental property which has become accepted in some churches but which they do not recognize as a substantive part of Christianity. Similarly, for some participants, such a belief is troubling, because they reason that many "good" people will be unfairly condemned while some "bad" people could be saved, which smacks of hypocrisy. However, because they interpret the messages communicated by Alpha as representing the logic of Christianity, they reject not only Alpha's take on Christianity, but Christianity itself; in other words, they assume all Christians adhere to these beliefs, and participants' agnostic logic becomes ingrained.

\section{A Grounded Model of Institutional Persuasion}

In the final part of my analysis I offer a grounded model of institutional persuasion that seeks to contextualize over time 1) the strategies and tactics deployed by persuaders, and 2) the responses of targets. In doing so the model incorporates my findings about the factors that underpin the resonance of each strategy as the well as different outcomes of the persuasive process, as shown in Figure 1. The model distinguishes between two phases and assumes that targets assess the resonance of the communication 
strategies of the message senders in each phase. Note that these phases are not clearly bounded, but represent the difference in emphasis that I observed between the nature of messages communicated in the early part of the persuasive process vis-à-vis the later part of the persuasive process.

Specifically, the model posits an early focus on framing and identity work, switching to a focus on affective and performative work as the process unfolds. Turning first to framing work, a core emphasis of phase 1 is on reason and argumentation. Note that this is the only form of communication that includes a feedback arrow, indicating that persuaders alter subtly their messages to justify apparent contradictions highlighted by message recipients. On Alpha, messages emphasize that Christianity has been misconstrued in the media and popular culture, and 'evidence' is offered for the existence of God. These messages are supported with statements from Christians with high levels of legitimacy.

Identity work designed to build and show the importance of community also features prominently in the first phase. Here, two different tactics are emphasized: one highlights community building at a group level, a second stresses links to a broader movement. In the context of Alpha, some community building messages are intended to convey the sense that course participants are on a "journey" to faith together. Other community building messages sought to highlight connections to the wider Christian movement.

The model assumes that the resonance of framing work is underpinned by message consistency and the perceived charisma of the persuaders. The resonance of identity work is underpinned by the extent to which targets perceive there to be a connection with one another. Should either or both of these forms of work fail to resonate, the result is logic maintenance, as indicated by the diagonal arrow in the figure - the existing institutional logic held by the target is unchanged. In addition to the effectiveness of the communication, the initial openness of targets to the logic in question influences this outcome. If, however, both types of work resonate, targets' interest in the persuasive process deepens and they move to phase 2 as engaged participants.

As the process moves into its second phase the emphasis changes: efforts to persuade increasingly rely on facilitating the emotional and physical embodiment of the messages. The denser arrows that emanate from box 3 (affective work) and box 4 (performative work) indicate the greater intensity of the 
messages being conveyed. Thus the model indicates that the process of institutional persuasion begins at a relatively low degree of intensity, but that the intensity increases at a later stage. The Alpha course starts with discussion of relatively uncontroversial topics. As the course progresses, the intensity is amplified with the focus turning to more provocative topics. The messages being communicated also begin to be infused with emotion, and participants are encouraged to become physically involved in the proceedings: particular rituals are intended to reify the persuasive process and encourage participants to "believe".

The resonance of affective work is underpinned by the ability of persuaders to regulate the emotions of targets. The resonance of performative work is underpinned by targets' perception of the authenticity of the performances. If the communication is ineffective and one or both of these types of work fail to resonate with targets, the outcome is logic maintenance. If, however, targets feel that they have 1) invested heavily in the persuasive process, and 2) been subject to manipulation on the part of the persuaders, these strategies resonate negatively and the outcome is alienation - targets feel hostility towards the new logic and their existing logic becomes entrenched. Finally, if both affective and performative work resonate, the outcome is conversion: targets internalize the new logic and the persuasive process achieves its intended effects.

\section{Discussion}

Persuasion and conversion are fundamental to institutional dynamics because they enable institutions to recruit new adherents. Yet institutional theorists' conceptualization of the process whereby actors are persuaded to convert to a new logic is undeveloped. I have sought to build a framework that explains how actors in organizations can purposely shape this process and to examine the responses of targets. There are limitations to the approach I have taken. For example, my study does not adequately take account of the individual-level traits of targets (cf., Pratt 2000). Moreover, there may be other kinds of institutional work that are crucial to institutional persuasion and conversion in other settings. Nonetheless, I believe my framework makes substantive contributions to research on the microfoundations of institutions.

\section{Emotion and Performance in Institutional Persuasion and Conversion}

Two of the four types of micro-institutional work outlined in my model - framing work and identity work 
- have been examined extensively in institutional theory as core mechanisms underpinning logic adoption. However, affective work and performative work have, in comparative terms, been neglected. By emphasizing the role of emotion and performance in connecting actors to institutional logics, I therefore make an important contribution to institutional research.

With respect to emotion, it is striking that institutional theorists have only recently begun to take this topic seriously. Indeed, while a number of researchers have acknowledged the role of emotions in institutional life (e.g., Creed et al. 2010; DiMaggio 1997; Scott 2008), only a small number has addressed it directly. A key contribution is offered by Creed et al. (2014) whose penetrating analysis illustrates how shame "drives the self-regulation that underpin persons' conformity to institutional prescriptions and institutional reproduction" (p. 275). Their framework offers a compelling explanation for why guilt, a similar emotion to shame, may be so effective as a tactic on Alpha. Emotions are also marginal to social movement research, where they have frequently been dismissed as "too personal, too idiosyncratic, too inchoate, or too irrational" for systematic analysis (Goodwin et al. 2007: 413). This is not to say that they have been ignored altogether. For example, Gamson (1995) and Benford (1997) have shown how social movements use injustice frames to help create a sense of outrage. However, in general social movements theory offers a passive conception of emotion - it tends to consider affectivity in the context of broader scripts that shape actors' experience of, and responses to, particular emotions (Taylor 2013).

Consistent with Creed et al. (2014), my study shows that emotions are highly idiosyncratic and rooted in complex actor-specific interactions that draw on, but are not determined by, broader cultural patterns. I suggest that emotions connect actors with institutional logics by amplifying the meaning of a particular idea or event; by infusing messages with broader significance and linking them to a wider system of interpretation. For example, in the case of Alpha the discussion of "sinful" behavior designed to promote guilt arousal connects participants with the idea of forgiveness, which is central to Christianity. Shared emotional experiences also help to build solidarity and a sense of shared identity with others who experience them. However, emotions are volatile and the invocation of emotion is unreliable as a persuasive device: targets may react in unpredictable ways, misinterpret particular signals, or feel 
intimidated, patronized or overwhelmed by the experience. My study shows that even the most skilled and charismatic leaders cannot easily manipulate the emotions of others - even when targets are relatively open to the ideas being promoted - or nullify the risks associated with affective work.

In my study of the Alpha course, the activation of emotion was to a large extent intertwined with the performance of rituals. Interestingly, institutional research on ritual performance is underdeveloped, with just a few exceptions: Anand and Watson (2004) conceptualize the Grammy awards as a tournament ritual and show how this "situated performance" shapes the field of music production by serving as a dominant reference point for field members; Dacin and Dacin (2008) look at how a distinctive ritual - the "Aggie Bonfire" at Texas A\&M University - became deinstitutionalized but left behind remnants that sparked the emergence of new practices; and Dacin et al. (2011) show how dining rituals at Cambridge University contribute to the maintenance of the British class system by socializing students into an elite professional-managerial class. Ritual and performance occupy a similarly marginal place in social movement research. While social movement researchers have noted the importance of ritual "as a form of symbolic expression through which communications concerning social relationships are passed on" (Porta and Diani 2006, p. 109), it is surprising that they have not engaged in a systematic analysis of ritual and performance. Even the work on religious movements, where ritual and performance might be expected to feature prominently, has not devoted significant attention to the topic (Shupe and Misztal 1998).

Thus a key contribution of this study is to show the critical role of performance, particularly ritual performance, in persuading actors to adopt a new institutional logic. Consistent with work in ritual studies (Alexander 2004; Turner 1969), my analysis suggests that rituals are on the one hand ideological; they are intended to convey a particular system of meaning to participants. But they are also designed to be sensory experiences; to generate penetrating emotional reactions so that participants are left in no doubt that what is happening is 'real'. The crucial insight is that participants' connection to an institutional logic may be physical. Note that this need not involve the apparent hysteria described by some informants, but simply a sense of calmness or the intuition that something 'feels right.' From this perspective, performance represents a way of helping participants to make sense of a particular logic: it is not simply 
the enactment of a script, it is designed to shape participants' perceptions and interpretations of the world around them. This might happen gradually, through repeated enactment of a ritual over sustained periods (e.g., Dacin et al. 2010), or more quickly through higher intensity rituals designed to achieve transformation and the construction of a new reality such as on the "Holy Spirit away day".

\section{The Microdynamics of Institutions: Communication as a Two-way Process}

While important advances have been made in understanding how organizations persuade others to convert to new or altered institutional logics, much of the literature has focused on institutional entrepreneurs at the field level (Lammers 2011). By contrast, the model that I have developed focuses on the individual level and explains both how actors seek to persuade others to internalize an institutional logic and, crucially, the possible reactions of, and outcomes for, the targets.

A core limitation of institutional theory's macro focus is that the dynamics between persuaders and targets remain poorly understood. Suddaby (2011, p. 184) describes the uncertainty about how institutions are communicated between actors as "a gaping hole in institutional theory." Most notably, a key shortcoming of institutional research, like organizational research more broadly, is that it represents a "sender-biased view" of persuasion that "downplays the interpretative propensities and capabilities of the alleged receiver" (Christensen and Cornelissen 2011, p. 391). Indeed, studies that consider failed cases of persuasion are remarkably rare. This has arguably led to a distorted conception of agency in institutional theory. The result is that while the agents of change - the institutional entrepreneurs - are endowed with significant agency, other actors are stripped of it.

By considering both successful and unsuccessful attempts at persuasion, I have been able to offer a more nuanced conception of agency than is often portrayed in the institutional literature. Notably, I show that targets are not simply passive recipients of persuasive communication: they may infer meaning that is different from the intended meaning, deliberately resist or distort messages, and play a key role in the construction of the message itself. Indeed, one of my key findings is the identification of a set of factors that influence how targets evaluate messages (see Table 4). A particularly interesting implication of my model is the effects of commitment and message intensity on targets who are not converted. Specifically, 
where such targets make only a limited commitment to the persuasive process and perceive the message intensity to be low, their views about the institutional logic being promoted are likely to remain unchanged. However, for non-converts who make a significant commitment to the persuasive process and perceive more intense pressure to change their beliefs, the risk is that some messages may resonate negatively (Koopmans and Lozak 2004). When this happens, targets may become alienated from, and develop hostility towards, the logic being promoted. This has the potential to inflict significant damage on an institution, because it may motivate targets to undermine the logic in the eyes of others.

\section{The Role of Emotion in Behavior Change}

As well as contributing to the institutional literature, my study offers insights for emotion research.

Considerable energy has been expended examining how emotions can be used to influence attitudes and behaviors (Fisher and Ashkanasy 2000). However, these studies almost invariably consider specific emotions in narrow domains. For example, Elfenbein (2007) highlighted that emotion researchers have focused on the effects of "affective experiences" on a limited set of "organizationally relevant attitudes" such as job satisfaction, organizational commitment, and strength of working relationships. While these effects are surely important, they do not call into question or alter actors' overarching belief systems (Petty and Cacioppo 1986). By contrast, my study is concerned with the role of emotion in a very different type of attitude change, one that is seldom contemplated by emotion researchers: the relinquishment of one way of seeing the world and the adoption of another. I show that emotions are embedded in meaning systems - institutional logics - that serve to connect particular beliefs to one another. For emotions to influence core attitudes and associated behaviors, they need to engage with - to both challenge and reinforce - discrete "regimes of practice" (Friedland 2013). This requires more than just the communication of particular emotions; it also involves the embodiment of emotion through performance coupled with the strategic use of language and the construction of a shared identity. In other words, I show how emotions can be systematically integrated into and deployed alongside multiple modes of communication in order to transform the way that people think and behave, and the possible unintended consequences of doing so. 


\section{References}

Alexander, J.C. 2004. Cultural pragmatics: Social performance between ritual and strategy. Sociological Theory 22(4) 527-573.

Alpha Course Manual. 2009. Explore the Meaning of Life. Alpha International, London.

Anand, N., M.R. Watson. 2004. Tournament rituals in the evolution of fields: The case of the Grammy Awards. Academy of Management Journal 47(1) 59-80.

Balch, R.W., D. Taylor. 1977. Seekers and saucers: The role of the cultic milieu in joining a UFO cult. American Behavioral Scientist 20(6) 839-860.

Bator, R., R. Cialdini. 2000. The application of persuasion theory to the development of effective proenvironmental public service announcements. Journal of Social Issues 56(3) 527-542.

Benford, R.D. 1997. An insider's critique of the social movement framing perspective. Sociological Inquiry 67(4) 409-430.

Bromley, D.G. 2011. New religions as a specialist field of study. P.B. Clarke, ed. The Oxford Handbook of the Sociology of Religion. Oxford University Press, Oxford, 724-741.

Brookes, A. 2007. The Alpha Phenomenon. Churches Together in Britain and Ireland, London.

Burgoon, M., N.E. Dunbar, C. Segrin. 2002. Nonverbal influence. J.P. Dillard, M. Pfau, eds. The Persuasion Handbook: Developments in Theory and Practice. Thousand Oaks, CA, 445-473.

Charmaz, K. 2008. Constructionism and the grounded theory method. J.A. Holstein, J.F. Gubrium, eds. Handbook of Constructionist Research. The Guildford Press, New York, 397-412.

Christensen, L.T., J. Cornelissen. 2011. Bridging corporate and organizational communication: Review, development and a look to the future. Management Communication Quarterly 25 383-414.

Cialdini, R.B. 2001. The science of persuasion. Scientific American 284(2) 76-81.

Cornelissen, J. 2011. Corporate communication: A guide to theory and practice. Sage, London. Cote, S. 2005. A social interaction model of the effects of emotion regulation on work strain. Academy of Management Review 30(3) 509-530.

Creed, W.E.D., R. DeJordy, J. Lok. 2010. Being the change: Resolving institutional contradiction through identity work. Academy of Management Journal 53(6) 1336-1364.

Creed, W.E.D., B. Hudson, G. Okhuysen, K. Smith-Crowe. 2014. Swimming in a sea of shame: Incorporating emotion into explanations of institutional reproduction and change. Academy of Management Review 39(3) 275-301.

Creed, W.E.D., J.A. Langstraat, M.A. Scully. 2002. A picture of the frame: Frame analysis as technique and as politics. Organizational Research Methods 5(1) 34-55.

Dacin, M.T., P.A. Dacin. 2008. Traditions as institutionalized practice: Implications for deinstitutionalization. R. Greenwood, C. Oliver, K. Sahlin, R. Suddaby, eds. The Sage Handbook of Organizational Institutionalism. Sage, London, 327-351.

Dacin, M.T., K. Munir, K., P. Tracey, P. 2010. Formal dining at Cambridge colleges: Linking ritual performance and institutional maintenance. Academy of Management Journal 53(6) 1393-1418.

DeJordy, R., F. Barrett. 2014. Emotions in institutions: Bullying as a mechanism of institutional control. Research on Emotion in Organizations 10 219-243.

Dillard, J.P., M. Pfau. 2002. The Persuasion Handbook. Sage, Thousand Oaks, CA.

DiMaggio, P. 1997. Culture and cognition. Annual Review of Sociology 23 263-287.

Durkheim, E. 1912/1996. The Elementary Forms of Religious Life. The Free Press, New York.

Eisenhardt, K.M., M.E. Graebner. 2007. Theory building from cases: Opportunities and challenges. Academy of Management Journal 50(1) 25-32.

Elfenbein, H.A. 2007. Emotion in organizations: A review and theoretical integration. Academy of Management Annals $1371-457$.

Fisher, C.D., N.M. Ashkanasy. 2000. The emerging role of emotions in work life: An introduction. Journal of Organizational Behavior 21(2) 123-129.

Foster, C. 2006. From Knightsbridge to the nations: the Alpha movement and the future of Christendom. Contemporary Review 288(1682) 320. 
Friedland, R. 2013. God, love and other good reasons for practice: Thinking through institutional logics. M. Lounsbury, E. Boxenbaum, eds. Institutional Logics in Action: Research in the Sociology of Organizations. Emerald, Bingley, 25-50.

Friedland, R. 2014. Divine institution: Max Weber's value spheres and institutional theory. P. Tracey, N. Phillips, M. Lounsbury, eds. Religion and Organization Theory: Research in the Sociology of Organizations. Emerald, Bingley, 217-258.

Friedland, R., R.R. Alford. 1991. Bringing society back in. W.W. Powell, P.J. DiMaggio, eds. The new institutionalism in organizational analysis. University of Chicago Press, Chicago, 232-263.

Gamson, W.A. 1995. Constructing social protest. H. Johnston, B. Klandermans, eds. Social Movements and Culture. University of Minnesota Press Minneapolis, 85-106.

Goodman, F.D. 2008. Speaking in Tongues: A Cross-cultural Study of Glossolalia. Wipf and Stock Publishers, Eugene, OR.

Goodwin, J., J.M. Jasper, F. Polletta. 2007. Emotional dimensions of social movements. D.A. Snow, S.A. Soule, H. Kriesi, eds. The Blackwell Companion to Social Movements. Blackwell, Oxford.

Greenwood, R., M. Raynard, F. Kodeih, E.R. Micelotta, M. Lounsbury. 2011. Institutional complexity and organizational responses. Academy of Management Annals 5 317-371.

Gumbel, N. 1991. Why Jesus? Kingsway, Eastbourne.

Gumbel, N. 2007. Alpha: Questions of Life. Kingsway, Eastbourne.

Gumbel, N. 2009. The Alpha Course Director's Handbook. Alpha International, London.

Heard, J. 2012. Inside Alpha: Explorations in Evangelism. Wipf and Stock Publishers, Eugene, OR.

Hibbert, S., A. Smith, A. Davies, F. Ireland. 2007. Guilt appeals: Persuasion knowledge and

charitable giving. Psychology \& Marketing 24(8) 723-742.

Hovland, C.I. 1959. Reconciling conflicting results derived from experimental and survey studies of attitude change. American Psychologist 14(1) 8-17.

Hunt, S. 2004. The Alpha Enterprise: Evangelism in a Post-Christian Era. Ashgate, Aldershot.

James, W. 1961/1902. The Varieties of Religious Experience. Collier Books, New York.

Jowett, G.S., V. O'Donnell. 2012. Propaganda and Persuasion. Sage, London.

Kaplan, S. 2008. Framing contests: Strategy making under uncertainty. Organ. Sci. 19(5) 729-752.

Kellogg, K.C. 2009. Operating room: Relational spaces and microinstitutional change in surgery. American Journal of Sociology 115(3) 657-711.

Kellogg, K.C. 2011. Challenging Operations: Medical Reform and Resistance in Surgery. University of Chicago Press, Chicago.

Kelman, H.C. 1958. Compliance, identification, and internalization: Three processes of attitude change. Journal of Conflict Resolution 2(1) 51-60.

Kilbourne, B., J.T. Richardson. 1989. Paradigm conflict, types of conversion, and conversion theories. Sociology of Religion 50(1) 1-21.

Koopmans, R., S. Olzak. 2004. Discursive opportunities and the evolution of right-wing violence in Germany. American Journal of Sociology 110(1) 198-230.

Kunda, G. 2006. Engineering Culture: Control and Commitment in a High-tech Corporation. Temple University Press, Philadelphia.

Lammers, J.C. 2011. How institutions communicate: Institutional messages, institutional logics, and organizational communication. Management Communication Quarterly 25 154-182.

Lawrence, T.B., R. Suddaby. 2006. Institutions and institutional work. S. Clegg, C. Hardy, T. Lawrence, W. Nord, eds. Handbook of organizations studies, 2nd Edition ed. Sage, London, 215-254.

Lofland, J., R. Stark. 1965. Becoming a world-saver: A theory of conversion to a deviant perspective. American Sociological Review 30 862-875.

Long, T.E., J.K. Hadden. 1983. Religious conversion and the concept of socialization: Integrating the brainwashing and drift models. Journal for the Scientific Study of Religion 22(1) 1-14.

Meyer, R.E., G. Hammerschmid. 2006. Changing institutional logics and executive identities: A managerial challenge to public administration in Austria. Amer. Behavioral Scientist 49(7) 1000-1014.

Miller, V.J. 2008. Consuming Religion. Continuum, New York, NY. 
Mohr, J.W., F. Guerra-Pearson. 2010. The duality of niche and form: The differentiation of institutional space in New York City, 1888-1917. Research in the Sociology of Organizations 31 321-368.

Petty, R.E., J.T. Cacioppo. 1986. The Elaboration Likelihood Model of Persuasion. Springer, New York.

Porta, D.D., M. Diani. 2006. Social Movements: An Introduction. Blackwell, Oxford.

Pratt, M.G. 2000. The good, the bad, and the ambivalent: Managing identification among Amway distributors. Administrative Science Quarterly 45(3) 456-493.

Pratt, M.G., C.K. Barnett. 1997. Emotions and unlearning in Amway recruiting techniques:

Promoting change through "safe" ambivalence. Management Learning 28(1) 65-88.

Rao, H., P. Monin, R. Durand. 2003. Institutional Change in Toque Ville: Nouvelle Cuisine as an Identity Movement in French Gastronomy1. American Journal of Sociology 108(4) 795-843.

Richardson, J.T. 1985. The active vs. passive convert: Paradigm conflict in conversion/recruitment research. Journal for the Scientific Study of Religion 24(2) 163-179.

Richardson, J.T., M. Introvigne. 2007. New religious movements, countermovements, moral panics, and the media. D.G. Bromley, ed. Teaching New Religious Movements. Oxford University Press, Oxford.

Robbins, T. 1988. Cults, Converts and Charisma: The Sociology of NRMs. Sage, Thousand Oaks.

Rossner, M., M. Meher. 2014. Emotion in ritual theories. Stets, J.E., J.H. Turner, eds. The Handbook of the Sociology of Emotions V2. Springer, London, 199-220.

Rutherford, A. 2009. From AA to Alpha. The Guardian July 10.

Scott, W.R. 2008. Institutions and Organizations: Ideas and Interests. Sage, London.

Scully, M.A., W.D. Creed. 2005. Subverting our stories of subversion. G.F. Davis, D. McAdam, W.

Richard, S. Mayer, N. Zald, eds. Social Movements and Organization Theory, CUP, Cambridge, 310-332.

Shupe, A.D., B. Misztal. 1998. Religion, Mobilization, and Social Action. Praeger, Westport, CT.

Smets, M., T. Morris, R. Greenwood. 2012. From Practice to Field: A Multilevel Model of PracticeDriven Institutional Change. Academy of Management Journal 55 877-904.

Snow, D.A. 2007. Framing processes, ideology, and discursive fields. D.A. Snow, S.A. Soule, H.

Kriesi, eds. The Blackwell Companion to Social Movements. Blackwell, Oxford, 380-412.

Snow, D.A., R. Machalek. 1984. The sociology of conversion. Annual Rev. of Sociology (10)167-190.

Straus, R.A. 1979. Religious conversion as a personal and collective accomplishment. Sociology of

Religion 40(2) 158-165.

Strauss, A.L., J. Corbin. 1990. Basics of Qualitative Research. Sage, Thousand Oaks, CA.

Stets, J.E., R. Trettevik. 2014. Emotions in identity theory. Stets, J.E., J.H. Turner, eds. The Handbook of the Sociology of Emotions V2. Springer, London, 33-49.

Stets, J.E., J.H. Turner, eds. 2014. The Handbook of the Sociology of Emotions V2. Springer, London.

Suddaby, R. 2011. How communication institutionalizes: A response to Lammers. Management Communication Quarterly 25 183-190.

Taylor, V. 2013. Social movement participation in the global society: Identity, networks, and emotions. J. van Stekelenburg, C. Roggeband, B. Klandermans, eds. The Future of Social Movement Research: Dynamics, Mechanisms, and Processes. University of Minnesota Press, Minneapolis.

Thornton, P.H., W. Ocasio, M. Lounsbury. 2012. The Institutional Logics Perspective: A New Approach to Culture, Structure, and Process. Oxford University Press, Oxford.

Tormala, Z.L., R.E. Petty. 2004. Resistance to persuasion and attitude certainty: The moderating role of elaboration. Personality and Social Psychology Bulletin 30(11) 1446-1457.

Turner, V. 1969. The Ritual Process: Structure and Anti-structure. Aldine, Chicago.

Turner, J. 2007. The sociology of emotions: Basic Theoretical Arguments. Emotion Rev. 1 340-354.

Voronov, M., R. Vince. 2012. Integrating emotions into the analysis of institutional work. Academy of Management Review 37 58-81.

Wentworth, W.M., D. Yardley. 1994. Deep sociality: A bioevolutionary perspective on the sociology of human emotions. D.D. Franks (ed.) Social Perspectives on Emotions v2. JAI, Greenwich CT, 21-55.

Wood, W. 2000. Attitude change: Persuasion and social influence. Ann. Rev. Psych. 51(1) 539-570. 
Table 1: Comparison of the 'old' logic held by participants prior to the course and the 'new' logic promoted by the Alpha Course

\begin{tabular}{|c|c|}
\hline $\begin{array}{l}\text { The 'old' logic held by targets prior to participating in } \\
\text { Alpha }\end{array}$ & The 'new' logic espoused by Alpha \\
\hline There may or may not be a God & $\begin{array}{l}\text { There is a God. Those that believe in him will have } \\
\text { "eternal life". Those that do not cannot enter the } \\
\text { Kingdom of Heaven }\end{array}$ \\
\hline $\begin{array}{l}\text { People are responsible for their own actions, both } \\
\text { "good" and "bad" }\end{array}$ & $\begin{array}{l}\text { God has a "plan" for all who believe in him and guides } \\
\text { those "prepared to do his will". The devil lies behind } \\
\text { "our own evil desires and temptations" }\end{array}$ \\
\hline $\begin{array}{l}\text { Meaning is constructed through practices rooted in } \\
\text { secular institutions such as the state, the family and the } \\
\text { professions }\end{array}$ & $\begin{array}{l}\text { Meaning is constructed through sacred practices and } \\
\text { rituals that allow people to "experience" the Holy } \\
\text { Spirit and his gifts }\end{array}$ \\
\hline $\begin{array}{l}\text { Family and friends are the main sources of community } \\
\text { and identity }\end{array}$ & $\begin{array}{l}\text { Members of the local church and the broader } \\
\text { evangelical movement are the main source of } \\
\text { community and identity }\end{array}$ \\
\hline
\end{tabular}

Table 2: The strategies of institutional persuasion

\begin{tabular}{|c|c|}
\hline Tactics associated with strategies & Strategies \\
\hline Confront stereotypes & \multirow{2}{*}{ Framing Work } \\
\hline Use legitimate actors to promote messages & \\
\hline Promote shared identity at micro-level & \multirow{2}{*}{ Identity Work } \\
\hline Link macro-level frames to level of the group & \\
\hline Elicit empathy & \multirow{2}{*}{ Affective Work } \\
\hline Promote guilt & \\
\hline Produce theatrical spectacle & \multirow{2}{*}{ Performative Work } \\
\hline Enable theatrical participation & \\
\hline
\end{tabular}

Table 3: Informant responses to persuasive attempts

\begin{tabular}{|c|c|c|c|c|c|}
\hline Informant & $\begin{array}{c}\text { Resonance: } \\
\text { framing work }\end{array}$ & $\begin{array}{c}\text { Resonance: } \\
\text { identity } \\
\text { Work }\end{array}$ & $\begin{array}{c}\text { Resonance: } \\
\text { affective work }\end{array}$ & $\begin{array}{c}\text { Resonance: } \\
\text { performative } \\
\text { work }\end{array}$ & Outcome \\
\hline 1 & $\checkmark$ & $\checkmark$ & $\checkmark$ & $\checkmark$ & Conversion \\
\hline 2 & $\checkmark$ & $\checkmark$ & $\checkmark$ & $\checkmark$ & Conversion \\
\hline 3 & $\checkmark$ & $\checkmark$ & $\checkmark$ & $\checkmark$ & Conversion \\
\hline 4 & $\checkmark$ & $\checkmark$ & $\checkmark$ & $\checkmark$ & Conversion \\
\hline 5 & $\checkmark$ & $\checkmark$ & $\checkmark$ & $\checkmark$ & Conversion \\
\hline 6 & $\checkmark$ & $\checkmark$ & $\checkmark$ & $\checkmark$ & Conversion \\
\hline 7 & $\checkmark$ & $\checkmark$ & $\checkmark$ & $\checkmark$ & Conversion \\
\hline 8 & $\checkmark$ & $\checkmark$ & $\checkmark$ & $\checkmark$ & Conversion \\
\hline 9 & $\checkmark$ & $\checkmark$ & $\checkmark$ & $\checkmark$ & Conversion \\
\hline 10 & $\checkmark$ & $\checkmark$ & $\checkmark$ & $\checkmark$ & Conversion \\
\hline 11 & $\checkmark$ & $\checkmark$ & $\checkmark$ & $\checkmark$ & $\checkmark$ \\
\hline 12 & $\checkmark$ & $\checkmark$ & $\checkmark$ & & $\checkmark$ \\
\hline 13 & $\checkmark$ & $\checkmark$ & $\checkmark$ & & $\checkmark$ \\
\hline 14 & $\checkmark$ & $\checkmark$ & & & $\checkmark$ \\
\hline
\end{tabular}




\begin{tabular}{|l|l|l|l|l|l|}
\hline 15 & $\checkmark$ & $\checkmark$ & $\checkmark$ & $\checkmark$ & Conversion \\
\hline 16 & $\checkmark$ & $\checkmark$ & $\checkmark$ & $\checkmark$ & Conversion \\
\hline 17 & $\checkmark$ & $\checkmark$ & $\checkmark$ & $\checkmark$ & Conversion \\
\hline 18 & $\checkmark$ & $\checkmark$ & $\checkmark$ & $\checkmark$ & Conversion \\
\hline 19 & $\checkmark$ & $\checkmark$ & $\checkmark$ & $\checkmark$ & Conversion \\
\hline 20 & $\checkmark$ & $\checkmark$ & $\checkmark$ & $\checkmark$ & Conversion \\
\hline 21 & - & $\checkmark$ & - & - & Maintenance \\
\hline 22 & $\checkmark$ & $\checkmark$ & - & - & Maintenance \\
\hline 23 & - & $\checkmark$ & - & - & Maintenance \\
\hline 24 & - & - & - & - & Maintenance \\
\hline 25 & $\checkmark$ & $\checkmark$ & - & - & Maintenance \\
\hline 26 & - & - & - & - & Maintenance \\
\hline 27 & - & $\checkmark$ & - & - & Maintenance \\
\hline 28 & - & - & - & - & Maintenance \\
\hline 29 & - & - & - & - & Maintenance \\
\hline 30 & - & - & - & - & Maintenance \\
\hline 31 & $\checkmark$ & $\checkmark$ & - & - & Maintenance \\
\hline 32 & - & - & - & - & Maintenance \\
\hline 33 & $\checkmark$ & $\checkmark$ & - & - & Maintenance \\
\hline 34 & $\checkmark$ & $\checkmark$ & - & - & Maintenance \\
\hline 35 & $\checkmark$ & $\checkmark$ & - & - & Maintenance \\
\hline 36 & $\checkmark$ & $\checkmark$ & X & X & Alienation \\
\hline 37 & $\checkmark$ & $\checkmark$ & X & X & Alienation \\
\hline 38 & $\checkmark$ & $\checkmark$ & X & X & Alienation \\
\hline 39 & $\checkmark$ & $\checkmark$ & X & X & Alienation \\
\hline 40 & $\checkmark$ & $\checkmark$ & X & X & Alienation \\
\hline
\end{tabular}

$$
\begin{aligned}
& \text { Legend, Table 3: } \\
& \checkmark=\text { strategy resonated } \\
& -=\text { strategy did not resonate } \\
& X=\text { strategy resonated negatively }
\end{aligned}
$$

\begin{tabular}{|c|c|}
\hline Factors underpinning outcomes & Outcomes of persuasion \\
\hline Perceived message consistency & \multirow{5}{*}{ Conversion } \\
\hline Perceived charisma of communicators & \\
\hline Perceived connection between the targets & \\
\hline Regulation of target emotions & \\
\hline Perceived authenticity of performances & \\
\hline Participants less open to messages & \multirow{2}{*}{ Maintenance } \\
\hline Ineffective Communication & \\
\hline Target investment in the persuasive process & \multirow{2}{*}{ Alienation } \\
\hline Perceived manipulation & \\
\hline
\end{tabular}

Table 4: Outcomes of the Persuasive Process 
Figure 1: A Model of Institutional Persuasion and Conversion

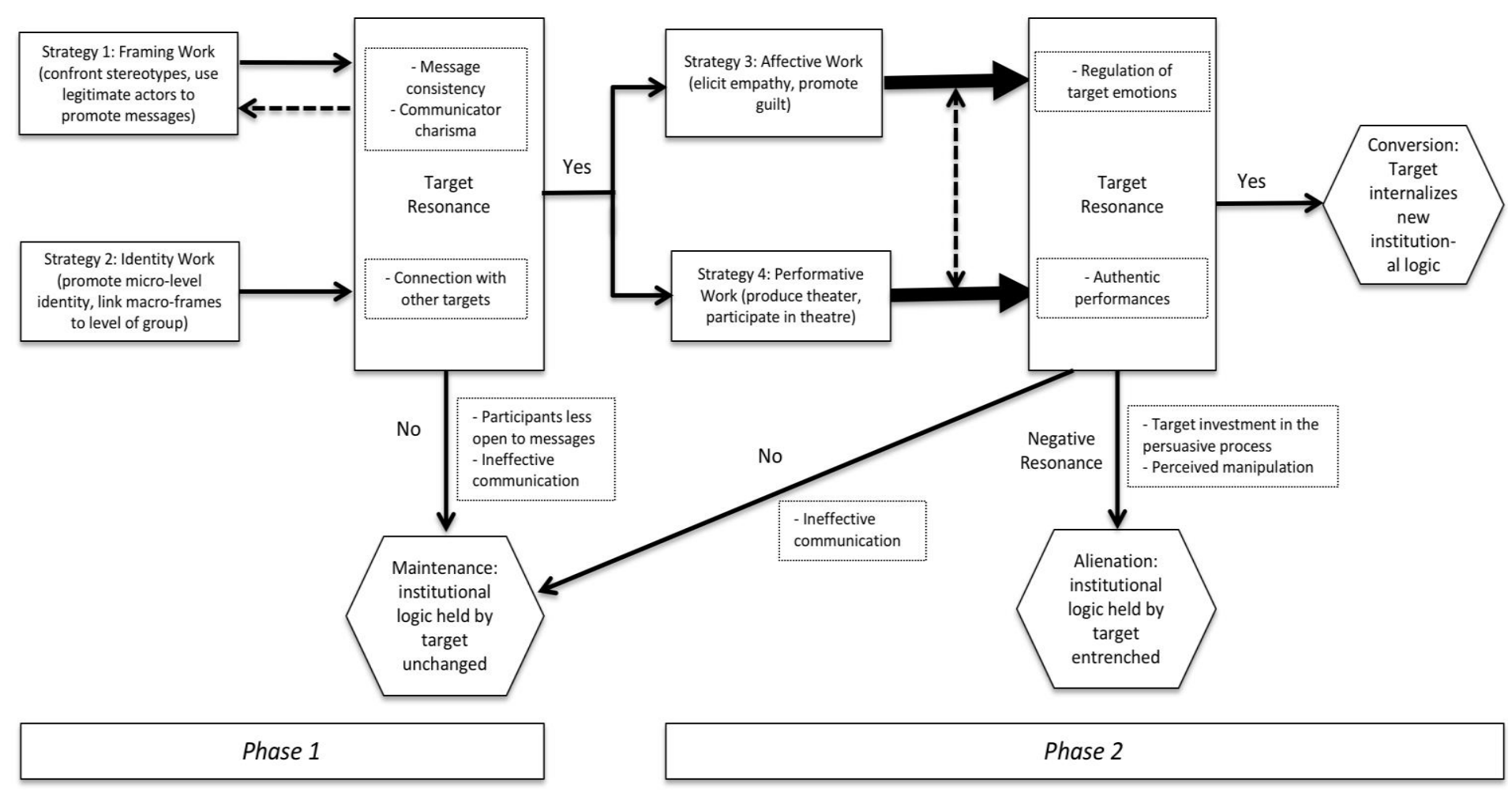

